\title{
C \\ VERSITA \\ Corruption and Information Sharing as Determinants of Non-Performing Loans
}

\author{
Fawad Ahmad
}

Department of Management Sciences, Iqra National University, Peshawar, Pakistan

\begin{abstract}
Background: There are several factors that lead to the growth or decline of the nonperforming loans, such as macroeconomic variables and bank specific variables, banks ownership structure, corruption and information sharing. Among them one of the main factors that affect the non-performing loans are the corruption. In developing countries corruption plays very important role in the growth of non-performing loans. Objectives: This study investigates the impact of corruption at economy level and institution level on the nonperforming loans. This study also examines the association of information sharing between depositors, lenders and financial institutions. Methods/Approach: The current study used time series data over the period of 2001 to 2010 and employed OLS method. Results: The results provide no significant association of corruption and information sharing with non-performing loans. Conclusions: The results suggest no significant impact of corruption on non-performing loans because of the nature of the data used, but as literature provides significant impact of corruption on non-performing loans, therefore State Bank of Pakistan and commercial banks can reduce the level of non-performing loans by reducing the chance of corrupt practices by following the rules and regulation of credit allocation, supervision and loan monitoring.
\end{abstract}

Key words: non-performing loans, corruption, information sharing, supervision, control and performance

JEL classification: G20, K4, P2

Paper type: Research article

Received: 8, November, 2012

Revised: 4, March, 2013

Accepted: 6, April, 2013

Citation: Ahmad, F. (2013). "Corruption and Information Sharing as Determinants of NonPerforming Loans ", Business Systems Research, Vol. 4, No. 1, pp. 87-98.

DOI: 10.2478/bsrj-2013-0008

\section{Introduction}

In order to achieve the recovery of global economy, the consumer and investor confidence in the markets must be restored. However, this process is very slow leaving many small economies, industries and even small firms struggling to attain break even. The impact of Global Financial Crisis (GFC) and recession in developing countries was most evident in 2009. Like in other Asian countries, GFC expressed its effects on the real sector of Pakistan economy. This partial affect was due to the decrease in the exports resulting from the recession and liquidity crunch in the global financial market, which lead to the withdrawal of foreign investment from Pakistan and depreciation of the local currency. Similarly, increase in global oil prices, energy crisis, underutilization of production facilities, high per unit cost, circular debts, decline in capital flow and growth, budget deficit and growth in corruption played important role in slowing down the recovery of economy. All these pressures on the economy and industry translated in the inability of households and firms to repay their debts, consequently resulting in the growth of Non-performing loans (NPLS). The rapid growth in NPLS poses challenges on the flexibility of banking sector to increase their provisions for NPLs. This affected the dividend payments, resulting in the decline of stock prices. 
Increase in NPLs is alarming sign for any country banking sector but growth in profitability can help in putting them out of sight. Same is the case with Pakistani banking sector, latest banking data collected by State Bank of Pakistan (SBP) shows that default rates has increased with rapid rate over the last few years. This upward trend started at the beginning of 2005 and lasted till the end of 2010. The NPLs to total bank lending was 6.7 percent in 2005 which jumped to 14.3 percent at the end of 2010 , showing growth of more than double during last five years. Whereas during the same period banks have shown growth in profitability, but despite of this banking sector struggled and invested mostly in government risk free securities. The main reason for growth in profitability was the higher spread earned by the banks, which was greater than 7 percent. The existing literature has shown that rapid growth in NPLs leads to the banking crisis (González, 1999). The GFC and recession in economy results in the growth of household and firms default rates, thus the quality of loan can be used to control and prevent the occurrence of banking crisis. The regulatory authorities can monitor the quality of loan and use it as early warning indicator to prevent the banking crisis.

There are several factors that lead to the growth or decline of the NPLs, such as macroeconomic variables and bank specific variables, banks ownership structure, corruption and information sharing. Among them one of the main factors that affect the NPLs is the corruption. In developing countries corruption play very important role in the growth of NPLs. This corruption can be at macroeconomic level, political corruption and inside institutions corruption. Existing studies have found significant positive impact of corruption on the growth of NPLs (Goel and Hasan, 2011). This growth in NPLs can be because of the political influence of the lenders (Khwaja and Mian, 2005), loans through bribes or banks official corruption, lenient credit policies, low opportunity cost of defaults, weak regulatory and supervisory authorities, corruption in financial institutions, failure of law implementation authorities, weak legal system of the country and information asymmetry between lenders and banks. Therefore the main goal of current study is to investigate the explanatory power of corruption (macro level and institution level) and information sharing as determinants of NPLs. This study used two indexes for the corruption measurement and one index for the information sharing. In this study 10 years time series data of NPLs ratio and five variables were used and ordinary least square method was employed to get the empirical results.

\section{Literature review and hypothesis}

The existing literature relating effects of corruption on the banks performance is limited. Only few studies have investigated the impact of corruption on the banks performance. Therefore to develop theoretical background for this study literature on corruption and its impacts on the bank lending and financial institutions performance are used. Only one recent study has empirically investigated the impact of corruption on NPLs (Goel and Hasan, 2011). In this study the link between NPLs and corruption is established by using existing literature on the relationship between corruption, non-financial institutions, legal system, protection to banks, banks lending and NPLs.

The key argument relating how corruption may hamper the bank lending can be given form the La Porta et al., (1997) study in which they presented the law and finance theory. Strong supervisory and legal institutions can increase the banks lending by ensuring the fulfillment of loan contacts, consequently providing the banks protection against the default of debtors. The enforcement of legal contracts by the legal institutions stimulates the willingness of the banks to lend more. Because banks are ensured that incase of debtors default, banks have the legal power laid down by legal institutions, to take actions in order to recover credit amount. These actions may include forcing the debtors to repay credit, disposing off collateral, and even take over of debtors businesses incase of corporate loans. Thus, the power to take action and imposition of legal contacts by the legal institutions increases the willingness and reduces the riskiness of the banks. Whereas, in case of corruption in the legal institution banks are unsure regarding the imposition and fulfillment of legal contracts and recovery of credits on debtors default. Thus uncertainty regarding the recovery of credit due to corruption results in the reduction of loans by the banks and also increases in the riskiness of banks in the form of NPLS. 
Existing empirical studies supported the fact that strong laws, supervision and legal institutions leads to improvement in banks financial records (reduction of loan losses) and growth in banks lending. For instance, La Porta et al., (1997) used 49 countries data and showed that the capital markets of the countries are smaller that are having poor investor protection laws. In other words they argued that poor protection laws do not provide the banks assurance that their credit will be repaid or not, thus lending by the banks is at lower side in such countries. Because of this reason the capital markets of such countries are less developed. On the other hand the countries with well developed legal institution and laws have well developed capital markets because banks has the assurance that they will get their credit back even in case of debtors default. Thus strong laws and legal institutions contribute to the increase in lending (Šarlija and Harc, 2012).

Djankov et al., (2007) used 129 countries credit data over the period of 25 years. Their study presented three main results; among them two are relevant to our study. First, they proved that information sharing among the institutions and legal protection to the creditor results in the development of credit markets by enhancing the credit growth. Second, they argued that the legal protection rights for creditors are different in both poor and rich countries. In rich countries strong legal protection rights are given to the creditors as compared to the poor countries where creditors have weak or no legal protection rights. Both these results show that strong legal protection rights results in the increase in banks lending. These results also suggest that the countries with strong legal protection can have lower levels of NPLs because of the strong legal protection and strict laws and regulations by the regulatory authorities. Similarly the poor countries where legal system is not very strong like Pakistan, banks in order to earn profit may lend to the low quality borrowers which takes the advantage of weak and corrupt legal system by not repaying loan. Thus the countries with weak legal system may have lower lending and higher NPLs. Barth et al., (2009) extended the work of Djankov et al., (2007) and find information sharing and competition play significant role in decreasing the lending corruption. They also find that information sharing increases the bank competition and reduces the banks curtail. They also argued that strong legal system also enhances the firm competition and reduces the corruption lending.

Qian and Strahan (2007) investigated the impact of different legal and institutional protection rights on the nature of ownership and banks terms of loans. They find that strong legal protections allow the banks to lend one specific sector or specific group of debtors. Similarly, strong protections reduce the riskiness of the banks and enable them to lend for long period of time and at lower interest rates.

Above arguments are relating the corruption in the judiciary and legal institutions, whereas another form of corruption that has effect on the bank credit is corruption by the bank official in the form of bribes received from the debtors. The bribes are given to the bank officials in order to favor debtors for lending money. This fact is clearly given in Levin and Satarov (2000) study that during 1990s in order to get loan Russian people used to give envelopes full of money to banks officials in order to get loans. This practice was part of Russian system at that time. Levin and Satarov (2000) also reported the criminal cases that were filled against the employees of banks during 1990s. In China during 2005, 461 similar corruption cases were registered; each case involved at least million Yuan corruption Barth et al., (2009). The corruption by the banks official can have both positive and negative impact on the bank lending.

The negative impact on bank lending is through the increase in the amount demanded by officials for allocating credit. This amount act as a cost for the debtors, if this cost will increase consequently the borrowing will reduce. The evidence relating negative relationship is provided by the World Business Environment Survey (WBES) conducted by World Bank. This survey used a questionnaire targeted the firms mangers to enquire whether banks mangers act as an obstacle in credit growth. Batra et al., (2004) conducted a research based on the WBES data and observed that $20 \%$ to $30 \%$ firms other than OECD countries considers bank officials as the moderator or major obstacle in the credit growth. Similarly, Beck et al., (2006) find negative relation between corruption and bank lending and argued that corruption of banking official is minor obstacle in lending. Their study was based on the WBES data and investigated the financing obstacles determinants by using 80 countries sample. They observed that half of the surveyed firms did not find corruptions in banks as an obstacle in 
lending. Thus it can be concluded from their results that corruption of banking officials can not be considered as determinant of obstacles in bank lending.

The above argument shows that corruption hampers the bank lending but corruption can also stimulate the growth of credit. The bribes by the debtors to the bank officials increase their chances of obtaining loan, thus corruption encourages banks lending.

The incentives to offer bribes increases for the borrower when banks are more risk averse. Risk aversion refers to unwillingness of banks in granting credits, as banks risk aversion increases consequently more loan applications are rejected. As a result chances to get loan through bribes increases. A theoretical evidence to support the positive relationship between lending and corruption was given by Stiglitz and Weiss (1981). They argued that adverse loan selection due to asymmetry of information between debtor and banks results into credit rationing. The credit rationing shows that debtors are willing to pay more than the credit rate, thus it provides incentive to debtor for paying bribes to get loan. In case of credit rationing banks avoids the adverse selection and grant loan to those who can pay more. Only bad borrowers are able to pay more thus avoidance of adverse selection attracts bad borrowers. According to adverse selection mechanism, only risky borrowers have incentives to pay more and to get loans, not the safe borrowers. Thus, corruption by the banks officials might only increase the bad loans of the banks.

The positive relation between corruption and lending is supported by Levin and Satarov (2000) they observe that corruptions in banks occure through bribes to bank officials for providing loans. Lizal and Kocenda (2001) argued that in Czech Republic corruption in lending is occured by allocating loans to the non-existent or unreasonable projects.

From an empirical point of view, only two studies are providing relation between the corruption and bank lending. First, Detragiache et al., (2008) investigated foreign bank penetration impact on the banks lending. Their study finds negative relationship between corruption and bank lending by using corruption as control variables. Second, Weill (2011) conducted empirical study to find the impact of corruption on bank lending in Russia. Results showed that corruption decreases the bank lending in Russia. In order to find the reason of this negative relation, Weill investigated whether negative relation is due to banks risk aversion or not, but find no support regarding the banks risk aversion impact on decrease in lending. Thus Weill argued that Russian government can increase the bank lending in order to increase the growth of country by controlling the corruption in country.

The only theoretical and empirical study that uses Pakistani data to provide evidence relating the corruption, political influence and NPLS was conducted by Khwaja and Mian (2005) by using corporate loan data over the period of 1996 to 2002. They conducted study by using data of 90,000 Pakistani firms. Their study investigated the influence of politically owned firm on the lending of banks. They classified the firms as political on the basis of any of its director participation in politics or election. They find that political firms lending is $45 \%$ greater than the other firms and they have $50 \%$ more default rates then other firms. They also argued that the government owned banks are the main creditors of the political firms as compared to the private banks, as they do not come under the political pressure. They also find the influence of the political firm increases when its director is in the government or the political party they are supporting is in power. They argued that the $50 \%$ increase in NPLs of political firms is due to the loan write-off or loan defaults. As the legal institutions are weak and influenced by the politician therefore no legal institution or regulatory authority can recover the default loans. As Khwaja and Mian (2005) have proved that in case of Pakistan political influence and corruption play important role in the increase in lending and NPLs, therefore in this study NPLs is used as dependent variable.

The only empirical study that empirically investigates the association between economy corruption and NPLs is conducted by Goel and Hasan (2011). They used large sample of over 100 countries with annual data of all the variables. They used 7 measures to investigate the impact of institutional corruption on NPLs. These measures are Corruption CPI, central bank autonomy, Membership of European Monetary Union, bank specific economy or not, development of financial sector, autonomous central bank or not and dummy variable for transition economy. They employed ordinary least square technique for the analysis. The results showed that more corrupt countries have high level of NPLs. The default rate are at lower level in economies that are having high growing rates, high lending rates and are in 
Euro zone. Further more the institutional factors such as financial underdevelopment, central bank autonomy, transition economies and bank based economies have no significant influence on the NPLS.

The above three studies (Goel and Hasan, 2011; Khwaja and Mian, 2005; and Weill, 2011) are relevant to this study. This study is similar to Goel and Hasan (2011) but differs in term of measures of corruptions. Before this study Goel and Hasan (2011) has investigated the direct relation between NPLs and corruptions by using the institution corruption measures. In this study all the explanatory variables of Goel and Hasan (2011) can not be used because their study was aimed at cross-country analysis of corruption whereas this study considers only one country. This study uses three measures of corruption that includes the corruption CPI, legal institutions corruption index and perception of corruption index, and one measure for information sharing. No existing study has used these three measures in single model to investigate their impact on NPLs.

Based on existing literature current study formulated three hypotheses relating association between NPLS and corruption and information sharing. The hypotheses are given below

$\mathbf{H 1}$ : The increase in corruption at macro (country) level has positive impact on the NPLs.

H2: The strength in legal rights (reduction in corruption at banks level) results in the decline in NPLS.

H3: The high level of credit depth of information results in the decline of NPLs.

H4: The growth in GDP results in the decline of NPLs.

H5: The increase in lending rate results in the growth of NPLs.

\section{Methodology}

The dependent variable for the measurement of NPLs used in the current study is NPLs/total advances. The existing studies relating the determinants of NPLs have used NPLs/total advances as the dependent variable, for instance, Dash and Kabra (2010); Louzis et al., (2010) and Festic et al., (2011), current study also uses NPLs/total advances as dependent variable.

The current study uses the survey conducted by Transparency International for measuring corruption in Pakistan. This survey contains many indicators that can be used to measure the level of corruption in specific country. The most important and relevant indicators to this study is perception relating corruption. This measure is based on the interview conducted from the mangers of businesses to ask how much they pay for the bribes. The smallest value of both measure are assigned values between " 0 " and " 10 ". High corruption is represented by value " 0 " and low or no corruption by "10". Thus countries with index value nearer to " 0 " are more corrupt and vice versa. The integral index for the perception of corruption is used by the existing empirical studies to measure corruption perception (Goel and Hasan, 2011; Méon and Sekkat, 2005; and Weill, 2011).

As discussed in the literature that strong legal and regulatory authorities supervision leads to the improvement of banks loan quality. Here a new measure for lenders and borrowers protection is used i.e. strength of legal rights index. This measure is given in the World Bank database for all the countries. This index measures the legal protection and rights relating bankruptcy and collaterals given to the lenders and borrowers for facilitating the credit. This measure will help to investigate that whether increase in legal protection to the borrowers and lenders decreases the NPLs or not. This index contains value from 0 to 6 , where " 0 " represents the low level of protection and "6" represents the high level of protection.

As discussed in the literature there are two types of corruption i.e. corruption in the macro level and corruption in banks level. The integral index for the perception of corruption will be used as macro level corruption and strength of legal rights index will be used to measure banks level corruption.

As suggested by Djankov et al., (2007) and Barth et al., (2009) that information sharing and competition play significant role in decreasing the lending corruption. Therefore this study uses Credit depth of information index to investigate the impact of information sharing on the NPLS because corruption in lending leads to the NPLS. Credit depth of information index measures the degree of information available to the customers by the private or public registries. This index contains value from 0 to 6 , where " 0 " represents the low level of 
information sharing and " 6 " represents the high level of information sharing. The credit depth of information index measure is given in the World Bank database for all the countries.

Existing literature also suggest that the increase in the lending rate and growth in the per capita income also influence the NPLs, thus these variables are used here as instrumental variables. The explanatory variables used in the current study are given in table 1 below. Table 1 contains the five explanatory variables i.e. Integral index for the perception of corruption and Strength of legal rights index to represent corruption at macro and institution level; Credit depth of information index to represent extent of information sharing between financial institutions, lenders and borrowers; lending rate and per capita income. The table 1 also provides the symbol of each variable that are used in the equation 1, the expected signs as provided by existing literature, data source and references of the existing studies using the same variables. The dependent variable for the measurement of NPLs used in the current study is NPLs/total advances.

\section{Table 1}

Explanatory variables, symbols, expected signs, data source and references

\begin{tabular}{|c|c|c|c|c|}
\hline $\begin{array}{c}\text { Explanatory variables } \\
\begin{array}{c}\text { Integral index for the } \\
\text { perception of corruption }\end{array}\end{array}$ & Symbol & Expected Sign & Data source & \multicolumn{1}{c|}{ References } \\
\hline $\begin{array}{c}\text { Strength of legal rights index } \\
\text { International }\end{array}$ & SLRI & - & World Bank & $\begin{array}{l}\text { Méon and Sekkat, 2005; } \\
\text { Weill, 201 1; and Goel and } \\
\text { Hasan, 2011 }\end{array}$ \\
\hline $\begin{array}{c}\text { Credit depth of information } \\
\text { Djankov et al., 2007 al., 1997; }\end{array}$ & CDII & - & World Bank & $\begin{array}{l}\text { Djankov et al., 2007; Qian } \\
\text { and Strahan, 2007; and } \\
\text { Barth et al., 2008 }\end{array}$ \\
\hline Lending rate & LR & + & IMF & Goel and Hasan, 2011 \\
\hline GDP per capita & GDP & - & IMF & Goel and Hasan, 2011 \\
\hline
\end{tabular}

This section used time series data of NPLs ratio and three variables. For each variable 10 years data was used. The data relating the NPLs ratio for whole Pakistani banking sector is given in the World Bank data base. Similarly the data relating corruption index is collected form transparency international, remaining variables data is collected from World Bank database. The annual data of all variables are used over the period of 2001-2010.

Previous studies have used ordinary least square method or panel data regression analysis. For instance, Weill (2011) and Goel and Hasan (2011) have used ordinary least square method to analyze the relationship between different corruption and bank lending. As this research is similar to Goel and Hasan (2011) and used time series data, therefore this study uses ordinary least square method.

In most econometric analysis before applying models variable are converted into log forms to remove heteroskedicity from the analysis and this process is know as log transformation. Where as, Luetkepohl and $X \cup(2009)$ demonstrated that log transformation is accurate in some special cases. Here the main aim is to capture the dynamics of NPLs; thus log transformation can produce downward bias during estimation. Therefore to capture the dynamics in NPLs, variable series are first converted into differences and then expressed as percentage change. After that unit root test is conducted to check for the stationarity of the variables. The stationarity of data means that most of the time series have constant mean and variance, which results in the false regression analysis with high R-squared value and few significant relationships between variables. Therefore this problem is solved by checking the time series for the unit root by using stationarity tests of Augmented Dickey Fuller (ADF), Dickey-Fuller GLS and Phillips-Peron (PP) unit root tests. If series are stationary at level then OLS is conducted by using the same values of the series but when series are stationary at first difference or second difference then OLS is also applied by using the first or second difference of the time series.

Before applying OLS explanatory variables are checked for the multicollinearity by using correlation matrix. The multicollinearity problem arises because of the high correlation between any explanatory variables. The multicollinearity problem makes the significant variables insignificant by increasing the $\mathrm{p}$-value; the increase in $\mathrm{p}$-value lowers the t-statistics 
value. Thus the OLS results with multicollinearity will show significant variables as insignificant variables. The multicollinearity problem is solved by dropping the high correlated variables and then regression is run after dropping highly correlated variables.

After getting results from the OLS, model is checked whether it can be used to predict the future results or the OLS model is best or not. There are certain features or characteristics of model through which it can be concluded that the model is good or not. First is the high Rsquared value with maximum number of significant relation and F-statistics value with $p$-value less than 5\%. Second, residuals are not serial correlated, third, residuals are not heteroskedastic but are homoskedastic and fourth, that residuals are normally distributed. When any OLS has above four features than such model is considered best model and has forecasting power to predict future changes in dependent variable. The correlation of the model can be checked with Breusch-Godfrey Serial Correlation LM Test. The heteroskedasticity in the residual is tested with Breusch-Pagan-Godfrey test and for checking the normality of the model Jarque-Bera statistics is used with its $p$-value.

The model for this section is given below

$N P L s_{t}=\beta_{0}+\beta_{1} \mathrm{IIPC}_{t}+\beta_{2} \mathrm{SLRI}_{t}+\beta_{3} \mathrm{CDII}_{t}+\beta_{4} \mathrm{LR}_{t}+\beta_{5} \mathrm{GDP}_{t}+\mu_{t^{---}}$

$N P L s_{t}$ is the dependent variable, banks riskiness (impaired loans to gross loans ratio) in time period " $t$ "

IIPC $_{t}$ is the integral index for the perception of corruption in time period " + "

$S L R I_{t}$ is the strength of legal rights index in time period " $\mathrm{t}$ "

$C D I I_{t}$ is the Credit depth of information index in time period " + "

$\mathrm{LR}_{t}$ is the lending rate in time period " $\mathrm{t}$ "

$\mathrm{GDP}_{t}$ is the GDP growth in the time period " $\mathrm{t}$ "

$\beta_{1}, \beta_{2}, \beta_{3}, \beta_{5}$ and $\beta_{5}$ are the respective co-effcient terms

" $\mu_{t}$ "is the error term

" $t$ " is the time period (2001 to 2010)

\section{Results}

The analysis of the Corruption and information sharing started with the selection of three indices to measure corruption and information sharing (i.e. integral index for the perception of corruption, strength of legal rights index and Credit depth of information index). Three indices and NPLs/total loans ratio are converted into differences and then expressed as percentage change. The percentage changes of the variables are taken to capture the dynamics of the variables over the period of time (Luetkepohl and XU, 2009). The unit root tests are conducted to check for the stationarity of the variables, current study used ADF, Dickey-Fuller GLS and PP stationarity tests. The results of unit root tests are given in table 2, suggesting that all the variables are stationary at level. Thus OLS can be applied by using the original percentage values of the variables.

Before applying OLS explanatory variables were checked for the multicollinearity by using correlation matrix. The multicollinearity problem arises because of the high correlation between any explanatory variables. The multicollinearity problem makes the significant variables insignificant by increasing their $p$-value; the increase in $p$-value lowers the t-statistics value. Thus the OLS results with multicollinearity will show significant variables as insignificant variables. The multicollinearity problem is solved by dropping the high correlated variable. The correlation matrix between variables is given in table 3 .

The results in table 3 suggest that there is no correlation between the explanatory variables, thus OLS can be applied by using all three explanatory variables. The OLS is applied by using three explanatory variables; the results of OLS are given in table 4 . The fitness of the model is predicted with the help of R-squared, F-statistics and number of significant relationship between NPLs and explanatory variables. The R-squared value for the model is 0.310913 , suggesting that almost $31 \%$ variance in NPLs are explained by three explanatory variables. The F-statistics of the model has a $p$-value of 0.8532 , suggesting that three variables can not influence the NPLs jointly. 
Table 2

Unit root tests results

\begin{tabular}{|c|l|r|r|r|}
\hline Levels & & ADF & ADF GLS & PP \\
\hline Intercept & NPLs & $-8.0993^{*}$ & $-5.8412^{*}$ & -1.9123 \\
\cline { 2 - 5 } & Integral index for the perception of corruption & -2.7098 & $-3.0513^{*}$ & $-4.4324^{*}$ \\
\cline { 2 - 5 } & Strength of legal rights index & $-5.0010^{*}$ & $-5.2950^{*}$ & $-9.0630^{*}$ \\
\cline { 2 - 5 } & Credit depth of information index & $-2.8466^{* * *}$ & $-3.0126^{*}$ & $-3.6727^{* *}$ \\
\cline { 2 - 5 } & GDP growth rate & $-3.58034^{* *}$ & $-3.7029^{*}$ & $-3.5804^{* *}$ \\
\cline { 2 - 5 } & Lending rate & $-2.8641^{* * *}$ & $-3.0638^{*}$ & $-3.7447^{* *}$ \\
\hline \multirow{3}{*}{$\begin{array}{l}\text { Intercept } \\
\text { and trend }\end{array}$} & NPLs & $-8.0993^{* *}$ & $-4.8988^{*}$ & 0.0317 \\
\cline { 2 - 5 } & Integral index for the perception of corruption & $-3.3605^{* * *}$ & $-3.5828^{* *}$ & -3.4434 \\
\cline { 2 - 5 } & Strength of legal rights index & $-4.6647^{* *}$ & $-5.3971^{*}$ & $-9.9250^{*}$ \\
\cline { 2 - 5 } & Credit depth of information index & -2.5994 & $-3.0392^{* * *}$ & -3.1583 \\
\cline { 2 - 5 } & GDP growth rate & $-3.2995^{* * *}$ & $-3.7515^{*}$ & $-3.2946^{* * *}$ \\
\cline { 2 - 5 } & Lending rate & $-2.6997^{* * *}$ & $-3.1157^{* * *}$ & $-3.7447^{* * *}$ \\
\hline
\end{tabular}

Note: Where ${ }^{*}$ represents significance level of $1 \%,{ }^{* *}$ represents significance level of $5 \%$ and

*** represents significance level of $10 \%$

Source: Authors calculation

Table 3

Correlation matrix of corruption and information sharing

\begin{tabular}{|c|c|c|c|c|c|}
\hline 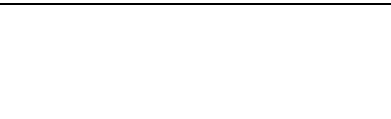 & $\begin{array}{l}\text { Integral index for } \\
\text { the perception of } \\
\text { corruption }\end{array}$ & $\begin{array}{l}\text { Strength of } \\
\text { legal rights } \\
\text { index }\end{array}$ & $\begin{array}{l}\text { Credit depth of } \\
\text { information } \\
\text { index }\end{array}$ & $\begin{array}{l}\text { GDP } \\
\text { growth } \\
\text { rate }\end{array}$ & $\begin{array}{l}\text { Lending } \\
\text { rate }\end{array}$ \\
\hline $\begin{array}{l}\text { Integral index for the } \\
\text { perception of corruption }\end{array}$ & 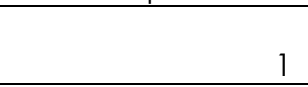 & & & & \\
\hline $\begin{array}{l}\text { Strength of legal rights } \\
\text { index }\end{array}$ & 0.1622 & 1 & & & \\
\hline $\begin{array}{c}\text { Credit depth of } \\
\text { information index }\end{array}$ & 0.4251 & 0.2019 & 1 & & \\
\hline GDP growth rate & -0.1224 & -0.3868 & 0.2641 & 1 & \\
\hline Lending rate & -0.1088 & -0.1212 & -0.6373 & -0.4359 & 1 \\
\hline
\end{tabular}

Source: Authors calculation

Table 4

OLS results and residual analysis of the model

\begin{tabular}{|c|c|c|c|c|}
\hline Variable & Coefficient & $\begin{array}{l}\text { Standard } \\
\text { Error }\end{array}$ & t-Statistic & Probability \\
\hline $\begin{array}{l}\text { Integral index for the perception of } \\
\text { corruption }\end{array}$ & 0.8245 & 1.3007 & 0.6339 & 0.5606 \\
\hline Strength of legal rights index & 0.6107 & 1.5827 & 0.3859 & 0.7192 \\
\hline Credit depth of information index & -1.2394 & 1.2426 & -0.9975 & 0.3750 \\
\hline GDP growth rate & -0.0966 & 0.2229 & -2.4336 & 0.6869 \\
\hline Lending rate & 0.4224 & 0.5688 & 3.7427 & 0.4989 \\
\hline $\mathrm{C}$ & 0.0083 & 0.1060 & 0.0781 & 0.9415 \\
\hline R-squared & 0.3109 & \multicolumn{2}{|l|}{ F-statistic } & 0.3610 \\
\hline Adjusted R-squared & -0.5505 & \multicolumn{2}{|c|}{ Probability (F-statistic) } & 0.8532 \\
\hline Durbin-Watson stat & & & & 1.0360 \\
\hline \multicolumn{5}{|l|}{ Breusch-Godfrey Serial Correlation LM test } \\
\hline Observed R-squared & 3.3099 & \multicolumn{2}{|c|}{ Probability Chi-Square } & 0.1911 \\
\hline \multicolumn{5}{|l|}{ Breusch-Pagan-Godfrey test } \\
\hline Observed R-squared & 7.3312 & \multicolumn{2}{|c|}{ Probability Chi-Square } & 0.1972 \\
\hline \multicolumn{5}{|l|}{ Normality test } \\
\hline Jarque-Bera & 0.7748 & \multicolumn{2}{|l|}{ Probability } & 0.6788 \\
\hline
\end{tabular}

Source: Authors calculation

The results in table 4 suggest that all three explanatory variables are insignificantly association with the NPLs, thus all three has no significant influence on the NPLs. The results 
provide positive association of NPLs with integral index for the perception of corruption, suggesting that corruption at macro level results in the growth of NPLs. This result provides the validity of $\mathrm{Hl}$ in terms of direction of association but the strength of association is insignificant. Thus it can be concluded that corruption at macro level has insignificant positive impact on NPLS. The justification for positive relation is that in country like Pakistan regulatory and supervisory authorities are very weak in regulating and implementing laws. Due to this lenders take advantage and do not repay loans because they know that no strong legal action will be taken against them. The other reason for the increase in NPLs is the corruption in the political system of the country. Most of the time political owned firms lend funds from the banks and by using the political power and corrupt practices do not repay loan (Khwaja and Mian, 2005). Similarly the management of the banks also by using corrupt practices lends money to low quality borrowers Barth et al., (2009), which results in the increase in NPLs.

The results suggest that NPLs are insignificantly positively associated with strength of legal rights index, thus rejects the validity of $\mathrm{H} 2$ in terms of Pakistani banking data. The existing studies suggest that with the increase in strength of legal rights lending in the country increases because of the assurance to the banks by the supervisory authorities that they will take all possible measures for the completion of loan contracts and repayment of default loans (La Porta et al., 1997; and Djankov et al., 2007). This shows that with the increase strength of legal rights protection NPLs must decline. But this study shows opposite result, the justification for the positive sign is that the laws and rules are improving every day in Pakistan, but the main problem is the implementation of the rules and laws. Countries like Pakistan have several laws for each and every department of the banks, but regulatory and supervisory authorities are very weak implementing the laws. This is the reason because of which with the increase in the strength of legal rights NPLs also increases.

The table 4 provides negative but insignificant association between NPLs and credit depth of information index, suggesting the validity of $\mathrm{H} 3$ in terms of sign between two variables. The results of current study suggest that the information sharing relating the credit requirements and regulations between potential lenders and banks leads to the decline in the NPLs, because it helps the banks to understand the demands and needs of the customers. Similarly it helps the lenders to fully understand the requirements, regulations and other legal aspects of the credit contract. This results in the proper fulfillment of the credit contracts and decrease in the NPLs. On the other hand information sharing reduces the chances of banks officials' corruption (Djankov et al., 2007; and Barth et al., 2009), because potential lenders now have all the information relating the rules and regulations of banks regarding loans. Therefore bank official cannot take any illegal step to grant loans to those who offer them money in exchange of granting loans. If bank official do any illegal act then potential lender can report to the bank or supervisory authority. This results in the allocation of loans to the quality borrowers and reduction of NPLs.

The negative relation suggests that growth in GDP increases the income of individuals, resulting in the increase in debt paying ability of individuals and decline in the NPLs ratio. The results confirm the validity of $\mathrm{H} 4$ of current study.

The results provide the significant negative association between lending rate and NPLs. The theoretical justification for the significant negative association is that with the increase in lending rate, deposits rates also increases. Individuals with the funds starts savings with banks to earn on their funds and investors with the profitable business projects feel reluctant to borrow and invest in projects whereas opposite is valid in case of decline in lending rate when individual and investors are more keen borrow for consumption and invest in risky projects. Thus savings in the economy increases and borrowing declines. Only those investors and individuals borrow, those are sure about the returns and success of their investments. Therefore, only those individuals and investors borrow that can return the principle plus interest of the bank, hence leading to the decline in borrowing and also in the NPLs level.

At the end of the analysis the residual of the model was checked for the existence of serial correlation, heteroskedasticity and normal distribution. Current study has used BreuschGodfrey Serial Correlation LM test to check for the serial correlation in the residual, the results of the test are given in table 4.

In Breusch-Godfrey Serial Correlation LM test the observed R-squared value and its probability is used to either accept or reject the null hypothesis of existence of serial correlation in the 
residual. The results in table 4 accepts the null hypothesis because the $\mathrm{p}$-value is greater than $5 \%$, suggesting that there is no serial correlation in the residual, which is desirable for a good regression model.

The heteroskedasticity of the residual was checked by using Breusch-Pagan-Godfrey test. In this test observed R-squared value and its probability is used to either accept or reject the null hypothesis of no existence of heteroskedasticity or existence of homoskedasticity. The results in table 4 accepts the null hypothesis because the p-value is greater than $5 \%$, suggesting that there is no heteroskedasticity in the residual and residuals are homoskedasticity, which is desirable for a good regression model.

At the end residuals are checked whether they are normally distributed or not. For this purpose Jarque-Bera statistics is normally used with its $p$-value to either accept or reject the null hypothesis of existence of normal distribution. The Jarque-Bera statistics and its $p$-value are given in table 4 . The results suggest that the $p$-value of Jarque-Bera statistics is greater than $5 \%$ thus the null hypothesis is accepted, suggesting that residuals are normally distributed.

\section{Discussion and conclusions}

The current study applied OLS to investigate the association of corruption and information sharing with NPLs. The results provided no significant association of two indices of corruption and one index of information sharing with NPLS. The results suggested positive relation of both measures of corruption with NPLs, suggesting that corruption positively impact the NPLs but its impact is insignificant. Furthermore results provided negative association between information sharing and NPLs, suggesting that with the increase in information relating loans, the level of NPLS can be decreased but the association is insignificant. The corruption and information sharing models were checked for the features of good regression model. The Rsquared value was low at $31 \%$ with no significant relation, residuals are not serially correlated, residuals are homoskedasticity and residuals are normally distributed.

The current study suggested no impact of corruption and information sharing on the NPLs, but as suggested by the literature corruption has significant impact on the NPLs. The justification for the insignificant association between NPLS and integral index for the perception of corruption is the methodology used to measure integral index for the perception of corruption. The integral index for the perception of corruption measure how corrupt the public sector of the country is perceived to be. It is a combination of polls and extracts from corruption related data collected by various reputable institutions. According to Transparency International corruption is the abuse of entrusted power for private gain by both public and private sectors. The integral index for the perception of corruption focuses on corruption which involves public officials, civil servants or politicians. The data sources used to compile the index include questions relating to the abuse of public power and focus on bribery of public officials, kickbacks in public procurement, misuse of public funds and on questions that probe the strength and effectiveness of anticorruption efforts in the public sector. The index covers both the administrative and political aspects of corruption. In producing the index, the scores of countries for the specific corruption related questions in the data sources are combined to calculate a single score for each country. The index does not contain the data collected from the banks therefore the relation between integral index for the perception of corruption and NPLs is insignificant, the more relevant corruption data related to banking sector can provide the significant association.

The SBP and commercial banks can reduce the level of NPLs by following the rules and regulation of credit allocation, supervision and monitoring of loans. The corrupt practices are most common in public banks, therefore as suggested above SBP of Pakistan should develop separate supervision policy for publically owned banks.

The corruption and information sharing model used OLS to test the empirical evidence; future studies can use the dynamic or advance models to overcome the data related problems and to get more accurate results. The current study used data of Pakistan only, therefore the findings of this study are not applicable in other countries, thus future studies can use the data of other developing or developed countries or panel of developing and developed countries. This will facilitate the use of advance panel data models and will 
provide more detailed and accurate information relating the impact of macroeconomic variables on NPLS.

\section{References}

1. Barth, J. R., Lin, C., Lin, P., Song, F. M. (2009), "Corruption in bank lending to firms: Crosscountry micro evidence on the beneficial role of competition and information sharing", Journal of Financial Economics, Vol. 91, No. 3, pp. 361-388.

2. Batra, G., Kaufmann, D., Stone, A. (2004), "The Firms Speak: What the World Business Environment Survey Tells Us about Constraints on the Private Sector Development", World Bank, Washington, DC.

3. Beck, T. H. L., Demirgüç, A. K., Laeven, L., Maksimovic, V. (2006), "The determinants of financing obstacles", Journal of International Money and Finance, Vol. 25, No. 6, pp. 932 952.

4. Dash, M. K., Kabra, G. (2010), "The Determinants of Non-Performing Assets in Indian Commercial Bank: An Econometric Study", Middle Eastern Finance and Economics, Vol.7, pp. 94-106.

5. Detragiache, E., Tressel, T., Gupta, P. (2008), "Foreign banks in poor countries: theory and evidence", Journal of Finance, Vol. 63, No. 5, pp. 2123-2160.

6. Djankov, S., McLiesh, C., Shleifer, A. (2007), "Private credit in 129 countries", Journal of Financial Economics, Vol.84, No. 2, pp. 299-329.

7. Festic, M., Kavkler, A., Repina, S. (2011), "The macroeconomic sources of systemic risk in the banking sectors of five new EU member states", Journal of Banking and Finance, Vol. 35, No 2. pp. 310-322.

8. Goel, R. K., Hasan, I. (2011), "Economy-wide corruption and bad loans in banking: international evidence", Applied Financial Economics, Vol. 21, No. 7, pp. 455-461.

9. González, B. H. (1999), "Determinants of ex-ante banking system distress: A macro-micro empirical exploration of some recent episodes", IMF Working Paper, No. 33.

10. Khwaja, A., Mian, A. (2005), "Do Lenders Favor Politically Connected Firms? Rent Provision in an Emerging Financial Market", The Quarterly Journal of Economics, Vol.120, No.4, pp. 1371-1411.

11. La Porta, R., Lopez, F. S., Shleifer, A., Vishny, R.W. (1997), "Legal determinants of external Finance", Journal of Finance, Vol. 52, No. 3, pp. 1131-1150.

12. Levin, M., Satarov, G. (2000), "Corruption and institutions in Russia", European Journal of Political Economy, Vol.16, No. 1, pp. 113-132.

13. Lizal, L., Kocenda, E. (2001), "State of corruption in transition: Case of the Czech Republic", Emerging Markets Review, Vol. 2, No. 2, pp. 137-159.

14. Louzis, D. P., Vouldis, A. T., Metaxas, V. L. (2010), "Macroeconomic and bank-specific determinants of non-performing loans in Greece: a comparative study of mortgage, business and consumer loan portfolios", Bank of Greece Working Paper, No 118.

15. Luetkepohl, H., XU, F. (2009), "The role of log transformation in forecasting economic variables", CESifo Working Paper Series, No. 2591.

16. Méon, P. G., Sekkat, K. (2005), "Does corruption grease or sand the wheels of growth", Public Choice, Vol. 122, No. 1-2, pp. 69-97.

17. Qian, J., Strahan, P. (2007), "How laws \& institutions shape financial contracts: the case of bank loans", Journal of Finance, Vol. 62, No. 6, pp. 2803-2834.

18. Stiglitz, J., Weiss, A. (1981), "Credit rationing in markets with imperfect information", American Economic Review, Vol. 71, No. 3, pp. 393-410.

19. Šarlija, N., Harc, M. (2012). "The impact of liquidity on the capital structure: a case study of Croatian firms", Business Systems Research, Vol. 3, No. 1, pp. 30-36.

20. Weill, L. (2011), "How corruption affects bank lending in Russia", Economic Systems, Vol. 35 , No. 2, pp. 230-243. 


\section{About the author}

Fawas Ahmed has recently complete MS in Finance from International Islamic University, Islamabad, Pakistan and is now serving as Lecturer in Finance in Iqra National University, Peshawar, Pakistan. The author is also member of Institute of Bankers Pakistan (IBP) and is the Junior Associate of IBP with specialization in Islamic finance. The areas of research interest are corporate finance, Islamic banking and traditional banking. Author can be contacted at fawad-624@hotmail.com 